\title{
NOVEHIY FAIR
}

British visual culture between Chartism and the Great Exhibition

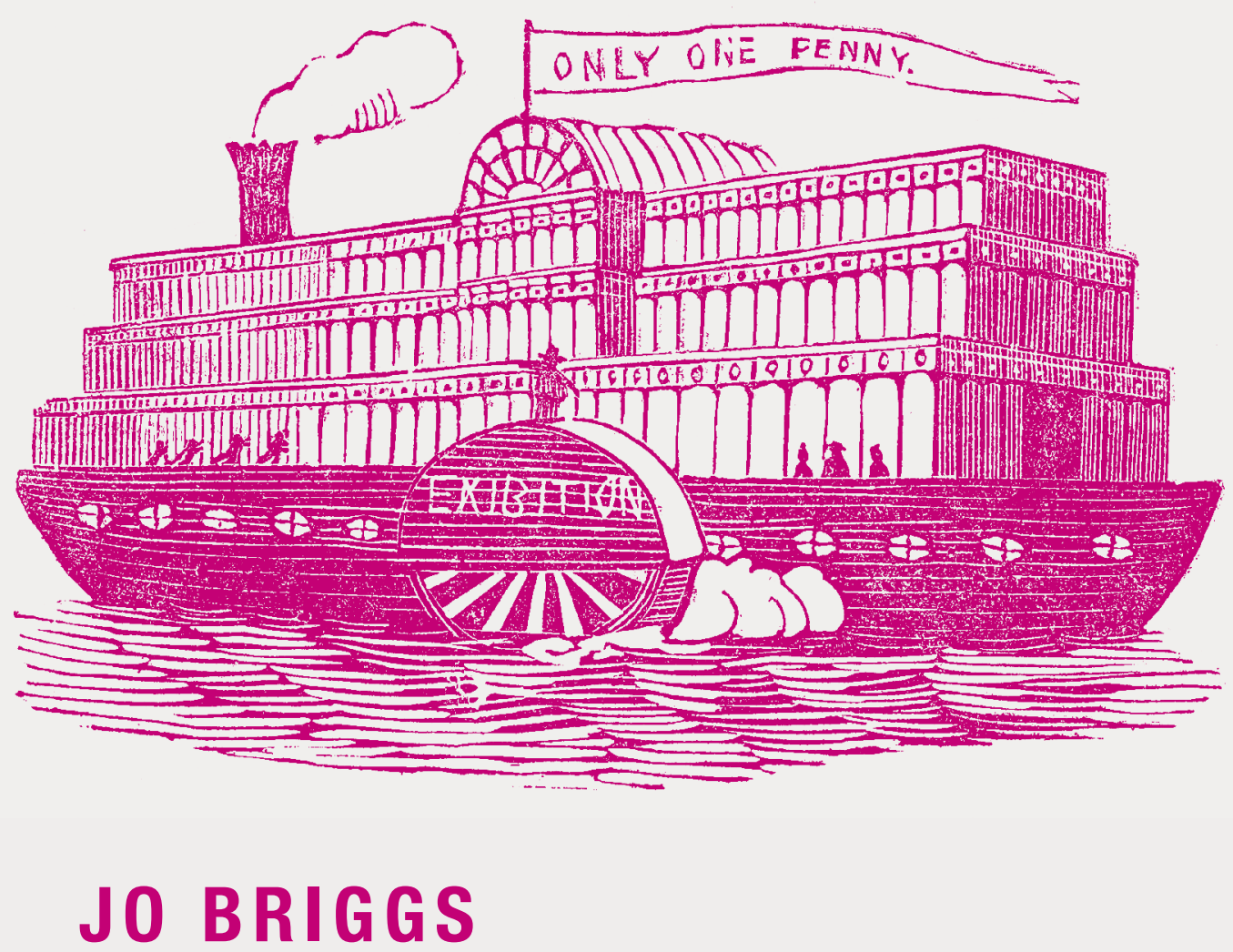


Novelty fair

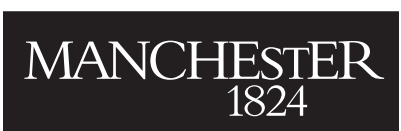

Manchester University Press 
Jo Briggs - 9781784997038 Downloaded from manchesterhive.com at $04 / 26 / 2023$ 12:52:19PM via free access 


\title{
Novelty fair
}

British visual culture between Chartism and the Great Exhibition

\author{
JO BRIGGS
}

Manchester University Press 
Copyright (C) Jo Briggs 2016

The right of Jo Briggs to be identified as the author of this work has been asserted by her in accordance with the Copyright, Designs and Patents Act 1988.

Published by Manchester University Press

Altrincham Street, Manchester M1 7JA

www.manchesteruniversitypress.co.uk

British Library Cataloguing-in-Publication Data

A catalogue record for this book is available from the British Library

Library of Congress Cataloging-in-Publication Data applied for

ISBN 9780719089640 hardback

First published 2016

The publisher has no responsibility for the persistence or accuracy of URLs for any external or third-party internet websites referred to in this book, and does not guarantee that any content on such websites is, or will remain, accurate or appropriate.

Typeset by

Servis Filmsetting Ltd, Stockport, Cheshire 